\title{
Pseudomonas fluorescens proliferates in a mouse organ homogenate at low temperature
}

\author{
YOTA TATARA $^{1}$, TAKAHIRO TERAKAWA ${ }^{2}$, YOUHEI YAMAGATA ${ }^{1}$ and TAKAFUMI UCHIDA ${ }^{1}$ \\ ${ }^{1}$ Laboratory of Enzymology, Graduate School of Agricultural Science, Tohoku University, 1-1 Tsutsumidori amamiya-machi, \\ Aoba-ku, Sendai, Miyagi 981-8555; ${ }^{2}$ Effector Cell Institute Inc., Aobadai 4-7-7, Meguro-ku, Tokyo 153-0042, Japan
}

Received December 5, 2007; Accepted January 28, 2008

\begin{abstract}
In this study we observed the proliferation of Pseudomonas fluorescens ( $P$. fluorescens) in mouse organ homogenates at $4^{\circ} \mathrm{C}$. P. fluorescens secreted a protease possessing properties different from those of the mammalian tissue proteases. The specificity of this protease required a basic amino acid residue at the $\mathrm{P}_{1}$ position at a $\mathrm{pH}$ optimum of 6.0. The specificity of the protease was similar to that of trypsin, but the $\mathrm{pH}$ optimum was different. The protease mildly degraded elastin-Congo red; this suggests that the protease serves as an alternative for elastase in the case of $P$. fluorescens strains that lack virulent elastase. The protease was identified as an alkaline protease of $P$. fluorescens by liquid chromatography-tandem mass spectrometry analysis. Our results show that proteome analysis of the soluble proteins is useful in identifying bacterial species, particularly the bacterial contaminants in samples containing antibiotics.
\end{abstract}

\section{Introduction}

Pseudomonas species are gram-negative bacteria indigenous to our environment, existing in, for example, drinking-water biofilms, the human skin and saliva (1-3). Indigenous microbiota have several beneficial effects on host physiological functions. Colonizing bacteria play a principal role in the postnatal maturation of the mammalian immune system

Correspondence to: Dr Takafumi Uchida, Graduate School of Agricultural Science, Tohoku University, 1-1 Tsutsumidori amamiya-machi, Aoba-ku, Sendai, Miyagi 981-8555, Japan

E-mail: uchidat@biochem.tohoku.ac.jp

Abbreviations: Boc, butyloxycarbonyl; EDTA, ethylenediaminetetraacetic acid; Glt, glutaryl; MCA, 4-methylcoumaryl-7-amide; MDR, multidrug resistance; MES, 2-morpholinoethanesulfonic acid; PMSF, phenylmethylsulfonyl fluoride; Suc, succinyl; Z, benzyloxycarbonyl

Key words: pseudomonas fluorescens, multidrug resistance, opportunistic infection, extracellular metalloprotease, indigenous bacterium, elastase
$(4,5)$. Pseudomonas aeruginosa (P. aeruginosa) and Pseudomonas fluorescens ( $P$. fluorescens) strains cause opportunistic infections. These organisms are generally able to acquire multidrug resistance (MDR) and cause nosocomial infections. Therefore, contamination by these species is one of the major problems in many hospitals (6). P. fluorescens is a member of the fluorescent pseudomonas group. The organism is generally considered to have a low level of virulence (7). Strains of $P$. fluorescens have frequently been identified as contaminants on human skin and as agents causing pseudobacteremia and procedure-related infections in hospitalized patients. In industrial environments, such as the dairy industry, the presence of $P$. fluorescens is undesirable since it is responsible for product spoilage due to the production of extracellular, heat-resistant lipases and proteases (8). $P$. aeruginosa, a species related to $P$. fluorescens, is an opportunistic pathogen that causes a variety of diseases, particularly in immunocompromised patients such as those suffering from cystic fibrosis where these bacteria preferentially colonize the bronchopulmonary tract (9). P. aeruginosa, a leading nosocomial pathogen, may acquire MDR. Infections caused by $P$. aeruginosa are often severe and life threatening. Moreover, they are difficult to treat because of their limited susceptibility to antimicrobial agents and the emergence of antibiotic resistance at a high frequency during therapy $(10,11)$, resulting in severe adverse outcomes (12). P. aeruginosa has 2 types of extracellular $\mathrm{Zn}$-metalloproteases, aeruginolysin (13) and pseudolysin (14). These proteases belong to the serralysin (15) and elastase families, respectively. Both proteases are virulence factors, contribute to tissue destruction, and assist in bacterial invasion during infection (16). The specific in vivo targets of aeruginolysin are not clearly known; the prospective candidates include the $\mathrm{Clq}$ and $\mathrm{C} 3$ proteins of the serum complement (17) as well as $\gamma$ interferon (18). Pseudolysin is one of the strongest virulence factors among the toxins of $P$. aeruginosa. It degrades the elastin of the human lung and also other matrix proteins, including laminin and collagen types III and IV $(19,20)$.

\section{Materials and methods}

All reagents were of analytical grade, and experiments involving animals were carried out in accordance with the guidelines established at Tohoku University, based on regulations and laws set by the Japanese government. 
Source. A brain was removed from a specific-pathogen-free (SPF) mouse, and the whole lateral hemisphere was immediately homogenized in 9 volumes of $50 \mathrm{mM}$ Tris- $\mathrm{HCl}$ (pH 7.4) containing $150 \mathrm{mM} \mathrm{NaCl}$. The homogenate was centrifuged at $10,000 \mathrm{x} \mathrm{g}$ for $10 \mathrm{~min}$ at $4^{\circ} \mathrm{C}$. The precipitate was suspended in 9 volumes of $50 \mathrm{mM}$ Tris- $\mathrm{HCl}(\mathrm{pH} 7.4)$ containing $150 \mathrm{mM} \mathrm{NaCl}$. This solution was used as a source of indigenous microbes and as the culture media.

Time course of the peptidase activity in culture medium. The mouse brain homogenate was incubated at 4 and $37^{\circ} \mathrm{C}$ for specific time intervals. The homogenate was then centrifuged at $15,000 \mathrm{x}$ g at $4^{\circ} \mathrm{C}$ for $10 \mathrm{~min}$. The supernatant was used as a crude enzyme solution and assayed for protease activity.

Enzyme assay. The hydrolysis of the fluorogenic peptide substrates was spectrofluorimetrically measured at $37^{\circ} \mathrm{C}$. The reaction mixtures contained $945 \mu \mathrm{l}$ of $50 \mathrm{mM}$ MES-NaOH buffer (pH 6.0), $5 \mu 1$ of $10 \mathrm{mM}$ substrate solution, and $50 \mu \mathrm{l}$ of sample enzyme in a total volume of $1 \mathrm{ml}$. The increase in fluorescence intensity produced by substrate cleavage during the incubation was measured at an emission wavelength of $440 \mathrm{~nm}$ with excitation at $360 \mathrm{~nm}$ using a fluorescence spectrophotometer. One katal of the enzyme activity was defined as the amount of enzyme that liberates $1 \mathrm{~mol}$ of 4-methylcounmaryl-7-amide (MCA) from a fluorogenic peptide substrate at $37^{\circ} \mathrm{C}$ and a $\mathrm{pH}$ of 6.0 .

Purification procedure. The mouse brain homogenate incubated at $4^{\circ} \mathrm{C}$ for $24 \mathrm{~h}$ was used as the starting material for the purification of the enzyme. All subsequent procedures were carried out at $4^{\circ} \mathrm{C}$. The homogenate was centrifuged at $15,000 \mathrm{x} \mathrm{g}$ for $10 \mathrm{~min}$. The supernatant was then applied to a HiLoad 16/60 Sephadex 200 column $(1.6 \mathrm{~cm}$ x $60 \mathrm{~cm}$; GE Healthcare, Uppsala, Sweden) equilibrated with $25 \mathrm{mM}$ sodium phosphate buffer ( $\mathrm{pH} 7.0$ ) containing $150 \mathrm{mM} \mathrm{NaCl}$. The enzyme was eluted using equilibration buffer. The fractions exhibiting Boc-Val-Leu-Lys-MCA hydrolyzing activity were pooled and dialyzed against $10 \mathrm{mM}$ sodium phosphate buffer, pH 7.0 (buffer A). The solution was applied to a HiTrap Q column (5 ml; GE Healthcare), and the enzyme was eluted using a linear gradient of $\mathrm{NaCl}$ at a concentration of $0-250 \mathrm{mM}$ in buffer A. The active fractions were pooled and dialyzed against buffer $\mathrm{A}$ and then applied to a Resource Q column (1 ml; GE Healthcare). Elution was performed using a linear gradient of $20-200 \mathrm{mM} \mathrm{NaCl}$. The purified enzyme migrated as a single band when subjected to sodium dodecyl sulfate-polyacrylamide gel electrophoresis (SDS-PAGE; 7\% gel) performed by Laemmli's method (21), as observed by Coomassie brilliant blue staining. Protein concentrations were measured by Bradford's method (22) using bovine serum albumin (BSA) as the standard protein.

Effects of inhibitors on activity. To investigate the inhibition of the protease, the enzyme was treated with various inhibitors at $37^{\circ} \mathrm{C}$ for $30 \mathrm{~min}$ at $\mathrm{pH} 6.0$ and the residual enzyme activity was measured. Control runs (100\% activity) were conducted by replacing the inhibitor solutions with distilled water. The following components were used: pepstatin A $(3 \mu \mathrm{g} / \mathrm{ml})$, leupeptin $(3 \mu \mathrm{g} / \mathrm{ml})$, phenylmethylsulfonyl fluoride (PMSF,
$5 \mathrm{mM})$, antipain $(3 \mu \mathrm{g} / \mathrm{ml})$, E-64 $(0.1 \mathrm{mM})$, and ethylenediaminetetraacetic acid (EDTA, $1 \mathrm{mM}$ ).

Determination of protein sequence. SDS-PAGE was carried out by Laemmli's method. The final acrylamide concentration of the separating gel was $12 \%(\mathrm{w} / \mathrm{v})$ and that of the stacking gel was $4 \%(\mathrm{w} / \mathrm{v})$. All samples were mixed with the same volume of $2 \mathrm{X}$ Laemmli sample buffer $(0.1 \mathrm{M}$ Tris-HCl buffer (pH 6.6), $200 \mu \mathrm{M}$ dithiothreitol (DTT), 4\% SDS, $0.2 \%$ bromophenol blue, and $20 \%$ glycerol), and denaturated at $98^{\circ} \mathrm{C}$ for $10 \mathrm{~min}$. After loading the samples, electrophoresis was carried out at a constant voltage of $80 \mathrm{~V}$ for $3 \mathrm{~h}$. After the electrophoresis, the gel was fixed for $1 \mathrm{~h}$ in $50 \% \mathrm{v} / \mathrm{v}$ methanol and $10 \% \mathrm{v} / \mathrm{v}$ acetic acid followed by staining with SYPRO Ruby stain (Bio-Rad Laboratories, Hercules, CA) overnight. The background stain was removed by incubation in $10 \% \mathrm{v} / \mathrm{v}$ acetic acid and $7 \% \mathrm{v} / \mathrm{v}$ methanol for $1 \mathrm{~h}$. The gels were stored in water at $4^{\circ} \mathrm{C}$. The stained band observed at approximately $45 \mathrm{kDa}$ on the SDS-PAGE gel was excised and chopped into small pieces. The gels were dried on a centrifugation evaporator without heating. Five microliters of $0.2 \%(\mathrm{v} / \mathrm{v})$ Tween-20 containing $20 \mathrm{mM}$ sodium bicarbonate buffer ( $\mathrm{pH} 8.0$ ) was added to swell the gel. A 5- $\mu 1$ volume of trypsin solution $(1 \mathrm{ng} / \mu \mathrm{l})$ was added to the above solution, and the mixture was incubated at $37^{\circ} \mathrm{C}$ for $30 \mathrm{~min}$. The gel was filled with $200 \mu \mathrm{l}$ of ammonium bicarbonate buffer $\left(\mathrm{pH} 8.0\right.$ ) and incubated at $37^{\circ} \mathrm{C}$ for $18 \mathrm{~h}$. The digestion was stopped by the addition of $5 \mu \mathrm{l}$ of formic acid. The sample was injected into a nano-LC system that was directly coupled to an electrospray ionization mass spectrometry (ESI-MS, HCT Ultra, Bruker Daltonik GmbH, Bremen, Germany). The MS and MS/MS data were acquired and processed automatically using the DataAnalysis software. Database searching was carried out using Mascot 2.0 (Matrix Science Ltd, UK, www.matrixscience.com) against the nonredundant protein sequence database of the National Center for Biotechnology Information (NCBI). All the peptide sequences were checked manually.

Elastin-Congo red assay. The elastolytic activity of the enzyme was tested by a modification of the procedures of Rust et al (23). Ten milligrams of elastin-Congo red (Sigma Chemical Co., St. Louis, MO) was suspended in $0.9 \mathrm{ml}$ of $50 \mathrm{mM}$ sodium acetate buffer $(\mathrm{pH}$ 6.0). The digestion reaction was initiated by the addition of the enzymes (final concentration of $1 \mu \mathrm{M}$ ) and then incubated at $37^{\circ} \mathrm{C}$ for $18 \mathrm{~h}$. The reactions were carried out in the absence or presence of $1 \mathrm{mM}$ EDTA. Finally, the reaction mixtures were centrifuged at $10,000 \mathrm{x} \mathrm{g}$ for $15 \mathrm{~min}$, and the absorption of the supernatants at $490 \mathrm{~nm}$ was recorded.

\section{Results and Discussion}

Proliferation of a microorganism in a mouse brain homogenate. A mouse brain homogenate was prepared and the time courses of the peptidase activity were recorded over a period of $24 \mathrm{~h}$ at 4 and $37^{\circ} \mathrm{C}$, respectively. When the homogenate was incubated at $4^{\circ} \mathrm{C}$, its hydrolytic activity against Boc-Val-Leu-Lys-MCA, Boc-Arg-Val-Arg-ArgMCA, and Boc-Gly-Arg-Arg-MCA at pH 6.0 increased 


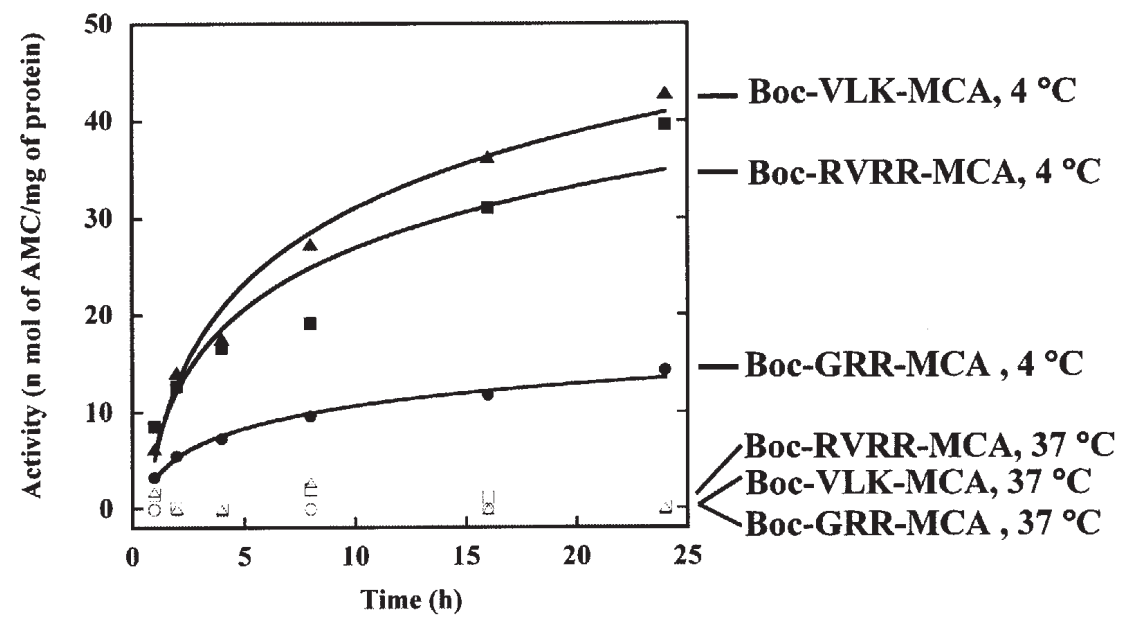

Figure 1. Curve demonstrating the increase in protease activity in a mouse brain homogenate at $4^{\circ} \mathrm{C}$ (closed symbols) and $37^{\circ} \mathrm{C}$ (open symbols). The mouse brain homogenate was incubated at 4 and $37^{\circ} \mathrm{C}$ respectively in order to increase the amount of indigenous bacteria and its secreted proteases. The homogenate supernatant was assayed for protease activity at $37^{\circ} \mathrm{C}$ for $1 \mathrm{~h}$ at $\mathrm{pH}$ 6.0. The synthetic substrates Boc-Val-Leu-Lys-MCA (circle), Boc-Arg-Val-Arg-Arg-MCA (square) and Boc-Gly-Arg-Arg-MCA (triangle) were used as substrates. The activity was defined as the increase in fluorescence intensity per total protein. The collected data from Boc-Val-Leu-Lys-MCA, Boc-Arg-Val-Arg-Arg-MCA, and Boc-Gly-Arg-Arg-MCA at $4^{\circ} \mathrm{C}$ were approximated to logarithmic curves.

Figure 2. SDS-PAGE analysis of the protease from a mouse brain homogenate. Approximately $2 \mu \mathrm{g}$ of the purified protein was separated under reducing-gel conditions (7\% gel) and stained with Coomassie brilliant blue. $\mathrm{M}$ represents the molecular mass marker. The homogeneous band was detected at $45 \mathrm{kDa}$.

logarithmically over the 24-h time course (Fig. 1), while at $37^{\circ} \mathrm{C}$, the peptidase activity did not increase. These results indicate that a certain psychrophilic microorganism preferentially proliferates in the mouse homogenate at low temperature and secrets a protease. It is considered that this microorganism exists as an indigenous bacterium; however, it proliferated only under temperature conditions equivalent to that of the mouse body. Diverse microbiota exist in the mammal intestine, stomach and skin (24-27). As the average body temperature of a mouse is approximately $37^{\circ} \mathrm{C}$, there is little information regarding the latent bacteria growing in the organs of this mammal at low temperature.

Purification of the protease and its enzymatic properties. In order to purify the protease that degrades Boc-Val-Leu-LysMCA at pH 6.0, successive chromatographies were performed.
A single band migrating during SDS-PAGE was obtained, as shown in Fig. 2. A 377-fold purification over the starting material was attained with approximately $29 \%$ recovery (Table I). The specific activity of the enzyme toward Boc-ValLeu-Lys-MCA was $4.36 \times 10^{-3} \mathrm{~kat} \mathrm{~kg}^{-1}$ protein. Its molecular mass was estimated to be $45 \mathrm{kDa}$ by SDS-PAGE. To investigate the inhibition of the purified protease, the enzyme was treated with various inhibitors at $37^{\circ} \mathrm{C}$ for $30 \mathrm{~min}$ at $\mathrm{pH} 6.0$ and the residual activity was measured. The enzyme activity was completely inhibited by antipain $(3 \mu \mathrm{g} / \mathrm{ml})$ and EDTA $(1 \mathrm{mM})$. Moreover, the activity appeared to be unaffected by pepstatin A $(3 \mu \mathrm{g} / \mathrm{ml})$, leupeptin $(3 \mu \mathrm{g} / \mathrm{ml})$, PMSF $(5 \mathrm{mM})$, and E-64 $(0.1 \mathrm{mM})$. The residual activity of the protease treated with these inhibitors was more than $90 \%$. Antipain is an aldehyde-type of inhibitor with an effective arginal residue, and it inhibits serine and cysteine proteases. The unidentified protease was considered to be a metalloprotease with an affinity towards antipain since EDTA completely inhibited its activity. To investigate the substrate specificity, 22 types of fluorogenic peptide substrates were used (Table II). The protease hydrolyzed the substrates containing the basic amino acid residues arginine or lysine at the $\mathrm{P}_{1}$ position and the amino acids with basic or large side chains at the $\mathrm{P}_{2}$ position. However, it did not hydrolyze substrates possessing non-basic amino acids at the $\mathrm{P}_{1}$ position and small size amino acids at the $\mathrm{P}_{2}$ position; this indicates that the enzyme has trypsin-like substrate specificity at a $\mathrm{pH}$ optimum of 6.0. Highly specific activity was observed against substrates with dibasic amino acids at the $\mathrm{P}_{1}$ and $\mathrm{P}_{2}$ positions, such as Boc-Gly-Arg-Arg-MCA and Boc-Arg-ValArg-Arg-MCA. The 45-kDa metalloprotease with trypsinlike substrate specificity was not observed in the mouse brain homogenate at an acidic $\mathrm{pH}$.

Identification of the microorganism. To identify the microorganism that proliferates in a mouse brain homogenate, the purified enzyme was degraded for a definite period by trypsin and analyzed by liquid chromatography-tandem mass 
Table I. Purification of a protease that cleaves the carboxyterminal end comprised of a pair of basic amino acids at pH 6.0 .

\begin{tabular}{lccccc}
\hline & $\begin{array}{c}\text { Total Protein } \\
(\mathrm{kg})\end{array}$ & $\begin{array}{c}\text { Total activity } \\
\left(\mathrm{mol} \mathrm{s}^{-1}\right)\end{array}$ & $\begin{array}{c}\text { Specific activity } \\
\left(\mathrm{mol} \mathrm{s}^{-1} \mathrm{~kg}^{-1}\right)\end{array}$ & $\begin{array}{c}\text { Yield } \\
(\%)\end{array}$ & $\begin{array}{c}\text { Purification } \\
(\text { fold })\end{array}$ \\
\hline Crude $^{\mathrm{a}}$ & $6.40 \times 10^{-5}$ & $7.39 \times 10^{-10}$ & $1.16 \times 10^{-5}$ & 100 & 1 \\
Sephadex 200 & $1.30 \times 10^{-5}$ & $5.84 \times 10^{-10}$ & $4.49 \times 10^{-5}$ & 79 & 4 \\
HiTrap Q & $3.04 \times 10^{-7}$ & $2.68 \times 10^{-10}$ & $8.83 \times 10^{-5}$ & 36 & 76 \\
Resource Q & $4.96 \times 10^{-8}$ & $2.16 \times 10^{-10}$ & $4.36 \times 10^{-3}$ & 29 & 377 \\
\hline
\end{tabular}

${ }^{a}$ Mouse brain homogenate incubated for 3 days at $4^{\circ} \mathrm{C}$ in order to increase indigenous bacteria and its secreted proteases.

Table II. Substrate specificity of the P. fluorescens alkaline protease from mouse brain homogenate.

\begin{tabular}{rrr}
\hline $\begin{array}{r}\text { Substrate } \\
\mathrm{P}_{3} \quad \mathrm{P}_{2} \quad \mathrm{P}_{1}\end{array}$ & $\begin{array}{c}\text { m katal } \\
(\mathrm{mol} / \mathrm{sec} \mathrm{kg})\end{array}$ & \\
\hline Boc-Gly-Arg-Arg-MCA & 33.2 & 100 \\
Boc-Arg-Val-Arg-Arg-MCA & 32.4 & 98 \\
Boc-Val-Leu-Lys-MCA & 5.8 & 18 \\
Boc-Leu-Lys-Arg-MCA & 4.6 & 14 \\
Boc-Glu-Lys-Lys-MCA & 2.9 & 9 \\
Boc-Ala-Gly-Pro-Arg-MCA & 1.0 & 3 \\
Z-Phe-Arg-MCA & 0.3 & 1 \\
Boc-Leu-Gly-Arg-MCA & N.D. & 0 \\
Boc-Gln-Gly-Arg-MCA & N.D. & 0 \\
Boc-Leu-Thr-Arg-MCA & N.D. & 0 \\
Arg-MCA & N.D. & 0 \\
Lys-MCA & N.D. & 0 \\
Ac-Asp-Glu-Val-Asp-MCA & N.D. & 0 \\
Suc-Leu-Leu-Val-Tyr-MCA & N.D. & 0 \\
Z-Leu-Arg-Gly-Gly-MCA & N.D. & 0 \\
Suc-Gly-Pro-Leu-Gly-Pro-MCA & N.D. & 0 \\
Suc-Ile-Ile-Trp-MCA & N.D. & 0 \\
Z-Val-Lys-Met-MCA & N.D. & 0 \\
Glt-Ala-Ala-Phe-MCA & N.D. & 0 \\
Suc-Ala-Pro-Ala-MCA & N.D. & 0 \\
Suc-Ala-Ala-Ala-MCA & N.D. & 0 \\
Phe-MCA & N.D. & 0 \\
\hline
\end{tabular}

N.D., not detected.

spectrometry (LC-MS/MS). Ten sequences were detected by LC-MS/MS analysis of the trypsin-digested protein, and they matched with the sequence of the $P$. fluorescens alkaline protease (Entrez protein accession ID: BAA36461) on the nonredundant protein sequence database of NCBI using the Mascot algorithm (Fig. 3). The sequence coverage was $24 \%$. The score of the Mascot search was 727 indicating high confidence. The $P$. fluorescens alkaline protease gene $\left(A p r A_{P F 33}\right)$ is clustered with the genes coding for the lipase $\operatorname{lip} \mathrm{A}_{\mathrm{PF} 33}$, the $\mathrm{ABC}$-exporter $\mathrm{AprDEF}_{\mathrm{PF} 33}$, and 2 homologues of the Serratia serine protease, namely, PspA and PsPB (28).

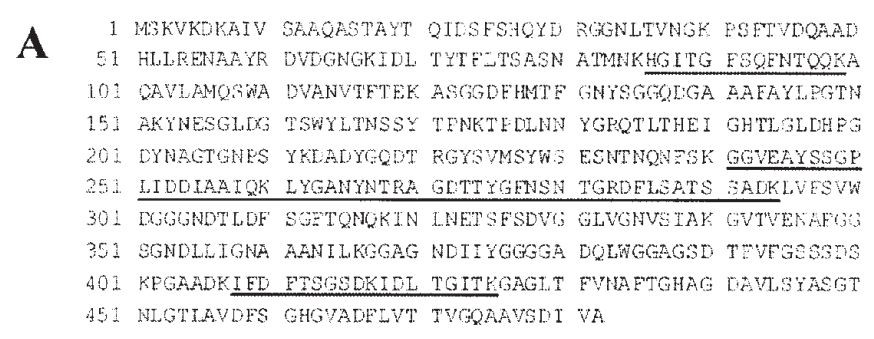

B

\begin{tabular}{|c|c|c|c|}
\hline $\mathrm{Mr}$ (spt.) & Mr (calc) & Delta & Scquence \\
\hline 1592.045 & 1591.774 & 0.2712 & HGITGFSOFN TQQK \\
\hline 1592.048 & 1591.774 & 0.2739 & HGITGFSQFNTQQK \\
\hline 1048.645 & 1048.494 & 0.1517 & TPDI.NNYGK \\
\hline 1048.725 & 1048.494 & 0.2317 & TPDL NNYGR \\
\hline 2003.205 & 2003.021 & 0.1844 & GGVEAYSSGPLIDDIAAIOK \\
\hline 2003225 & 2003.21 & 02044 & GGVFAYSSGPI IDDIAAIOK \\
\hline 2003.305 & 2003.021 & 0.2844 & GGVEAYSSGPLIDDIAAIQK \\
\hline 1070.585 & 1070.515 & 0.071 & L.YGANYNTR \\
\hline 1070.645 & 1070.515 & 0.131 & LYGANYNTR \\
\hline 1070.645 & 1070.515 & 0.131 & LYGANYNTR \\
\hline 1070.645 & 1070.515 & 0.131 & LYGANYNTR \\
\hline 1459,785 & 1459.633 & 0.1527 & AGDTTYGFNSNTGR \\
\hline 1459.785 & 1459.633 & 0.1527 & AGDTTYGFNSNTGR \\
\hline 1459.785 & 1459.633 & 0.1527 & AGDTTYGFNSNTGR \\
\hline 1140.665 & 1140.53 & 0.1356 & DFI.SATSSADK \\
\hline 1140.685 & 1140.53 & 0.1556 & DFLSATSSADK \\
\hline 1140.705 & 1140.53 & 0.1756 & DFLSATSSADK \\
\hline 2233.38 .5 & 2233.159 & 0.2265 & INLNETSFSDVGGLVGN VSIAK \\
\hline 2233.448 & 2233.159 & 0.2893 & INLNETSFSDVGGLVGNVSIAK \\
\hline 1115.685 & 1115.514 & 0.172 & IFDFTSGSDK \\
\hline 1115.745 & 1115.514 & 0.232 & IFDFTSGSDK \\
\hline 1957.298 & 1957.004 & 0.2938 & IFDFTSGSDKIDLTTGITK \\
\hline 859.7254 & 859.5015 & 0.224 & IDETGITK \\
\hline
\end{tabular}

Figure 3. Identification of the protease purified from a mouse brain homogenate by LC-MS/MS and Mascot search. (A) Amino acid sequence of the $P$. fluorescens alkaline protease (Entrez protein accession ID: BAA36461). Ten sequences were detected by LC-MS/MS analysis of the trypsin-digested protein, and they matched the sequence of the $P$. fluorescens alkaline protease on the nonredundant protein sequence database of NCBI using the Mascot algorithm. The underlined regions represent the matched sequence that covers $24 \%$ of $P$. fluorescens alkaline protease. (B) Molecular masses of tryptic peptides and their agreement with the identified sequences.

The enzyme hydrolyzes azocasein optimally at $\mathrm{pH} 8.0$ and therefore it is named alkaline protease $(29,30)$. The unidentified microorganism that proliferated in the mouse brain homogenate at $4^{\circ} \mathrm{C}$ was indicated to be $P$.fluorescens. It was assumed that $P$. fluorescens existed as an indigenous bacterium and proliferated when the host tissue was destroyed. These bacteria can survive in poor nutrient 
conditions, and they exist in our living environment. They can grow over a wide range of temperatures $\left(0-32^{\circ} \mathrm{C}\right)(31)$. In spite of careful procedures and aseptic manipulations, it is possible that $P$. fluorescens contaminated the mouse brain homogenate during experimental procedures. The psychrophile may have existed as an indigenous bacterium in the skin of the SPF mouse. We consider that the proliferation of $P$.fluorescens is suppressed under the high body temperatures in a mouse and that it proliferated in the mouse brain homogenate at $4^{\circ} \mathrm{C}$.

The role of the Pseudomonas fluorescens alkaline protease. The substrate specificity of the $P$. fluorescens alkaline protease appeared to be governed by the presence of a basic residue at the $\mathrm{P}_{1}$ position and a pair of basic amino acids at the $\mathrm{P}_{1}$ and $\mathrm{P}_{2}$ positions at $\mathrm{pH} 6.0$ (Table II). This is in accordance with reported data for the serralysin family proteases from $P$. fluorescens 114 (32). P. fluorescens is considered to have a low level of virulence. On the other hand, $P$. aeruginosa is an opportunistic pathogen. The $P$. aeruginosa elastase (pseudolysin) is an extracellular metalloprotease and is one of the strongest virulence factors among the toxins of this bacterium. Elastase from $P$. fluorescens was not detected in the present study. Therefore, the elastase activity of the alkaline protease of $P$. fluorescens was examined. The enzyme appeared to hydrolyze elastin-Congo red $\left(\Delta \mathrm{Abs}_{490}=0.078\right)$. This activity was inhibited in the presence of EDTA, which inhibits the $P$. fluorescens alkaline protease. It was surprising that the protease hydrolyzed elastin because peptide substrates of elastase, such as Suc-Ala-Pro-Ala-MCA and Suc-Ala-Ala-Ala-MCA, were not cleaved (Table II). Elastin is an important connective tissue protein that provides elasticity and tensile strength to organs, such as the skin, lung, blood vessels and ligaments (33). It is among the most hydrophobic proteins known. Although there is some species variation, approximately $75 \%$ of the entire sequence of elastin is made up of only 4 hydrophobic amino acids (Gly, Val, Ala, and Pro). The lysine residues of elastin are oxidatively deaminated by lysyl oxidase and are involved in covalent crosslinking $(34,35)$. The $P$. fluorescens alkaline protease does not appear to degrade elastin because it cleaves peptide substrates at the C-terminal end of basic amino acids. Trypsin, however, has a strict substrate specificity; it hydrolyzes only at the C-terminal end of the basic amino acids. It has been suggested that trypsin mildly hydrolyzes elastin (36). This is an interesting observation because $P$. fluorescens does not have an extracellular elastase; therefore, it is thought to have a low level of virulence. It is suggested that in case of $P$. fluorescens strains that do not secrete virulent elastase, the protease serves as an alternative for this enzyme.

The proteome analysis of the soluble protein in the sample. We successfully identified $P$. fluorescens contamination in a mouse organ homogenate by targeting its specific protease activity. P. fluorescens exists as an indigenous bacterium in our environment and can acquire MDR. It is possible that the bacterium contaminates samples and affects the compositions of proteins. Our findings provide novel insights into the bacterial biota that potentially exist in samples and demonstrate that proteome analysis of the soluble proteins is useful in the identification of bacterial species.

\section{Acknowledgements}

This work was supported by a Grant-in-Aid for Scientific Research on a Priority Area and a Grant-in-Aid for Scientific Research from the Ministry of Education, Culture, Sports, Science and Technology of Japan.

\section{References}

1. Schmeisser C, Stockigt C, Raasch C, Wingender J, Timmis KN, Wenderoth DF, Flemming HC, Liesegang H, Schmitz RA, Jaeger KE and Streit WR: Metagenome survey of biofilms in drinking-water networks. Appl Environ Microbiol 69: 7298-7309, 2003.

2. Baze PE, Thyss A, Caldani C, Juhlin L, Schneider M and Ortonne JP: Pseudomonas aeruginosa O-11 folliculitis. Development into ecthyma gangrenosum in immunosuppressed patients. Arch Dermatol 121: 873-876, 1985.

3. Kang JG, Kim SH and Ahn TY: Bacterial diversity in the human saliva from different ages. J Microbiol 44: 572-576, 2006.

4. Sudo N, Sawamura SA, Tanaka K, Aiba Y, Kubo C and Koga Y: The requirement of intestinal bacterial flora for the development of an IgE production system fully susceptible to oral tolerance induction. J Immunol 159: 1739-1745, 1997.

5. Hooper LV and Gordon JI: Commensal host-bacterial relationships in the gut. Science 292: 1115-1118, 2001.

6. Yetkin G, Otlu B, Cicek A, Kuzucu C and Durmaz R: Clinical, microbiologic, and epidemiologic characteristics of Pseudomonas aeruginosa infections in a University Hospital, Malatya, Turkey. Am J Infect Control 34: 188-192, 2006.

7. Simor AE, Ricci J, Lau A, Bannatyne RM and Ford-Jones L: Pseudobacteremia due to Pseudomonas fluorescens. Pediatr Infect Dis 4: 508-512, 1985.

8. Law BA, Andrew AT and Sharpe ME: Gelation of ultra-hightemperature-sterilized milk by proteases from a strain of Pseudomonas fluorescens isolated from raw milk. J Dairy Res 44: 145-148, 1977.

9. Gomez MI and Prince A: Opportunistic infections in lung disease: Pseudomonas infections in cystic fibrosis. Curr Opin Pharmacol 7: 244-251, 2007.

10. Carmeli Y, Troillet N, Eliopoulos G and Samore MH: Emergence of antibiotic-resistant Pseudomonas aeruginosa: comparison of risks associated with different antipseudomonal agents. Antimicrob Agents Chemother 43: 1379-1382, 1999.

11. Garner JS, Jarvis WR, Emori TG, Horan TC and Hughes JM: CDC definitions for nosocomial infections. Am J Infect Control 16: 128-140, 1988.

12. Carmeli Y, Troillet N, Karchmer AW and Samore MH: Health and economic outcomes of antibiotic resistant Pseudomonas aeruginosa. Arch Intern Med 159: 1127-1132, 1999.

13. Morihara K: Aeruginolysin. In: Handbook of Proteolytic Enzymes. A.J. Barrett, N. Rawlings and J.F. Woessner (eds). Academic Press, London, pp1150-1152, 1998.

14. Morihara K: Pseudolysin and other pathogen endopeptidases of thermolysin family. Methods Enzymol 248: 242-253, 1995.

15. Maeda $\mathrm{H}$ and Morihara K: Serralysin and related bacterial proteinases. Methods Enzymol 248: 395-413, 1995.

16. Kawaharajo K, Homma JY, Aoyama Y and Morihara K: In vivo studies on protease and elastase from Pseudomonas aeruginosa. Jpn J Exp Med 45: 89-100, 1975

17. Hong YQ and Ghebrehiwet B: Effect of Pseudomonas aeruginosa elastase and alkaline protease on serum complement and isolated components $\mathrm{C} 1 \mathrm{q}$ and $\mathrm{C} 3$. Clin Immunol Immunopathol 62: 133-138, 1992.

18. Horvat RT and Parmely MJ: Pseudomonas aeruginosa alkaline protease degrades human gamma interferon and inhibits its bioactivity. Infect Immun 56: 2925-2932, 1988.

19. Bejarano PA, Langeveld JP, Hudson BG and Noelken ME: Degradation of basement membranes by Pseudomonas aeruginosa elastase. Infect Immun 57: 3783-3787, 1989.

20. Saulnier JM, Curtil FM, Duclos MC and Wallach JM: Elastolytic activity of Pseudomonas aeruginosa elastase. Biochim Biophys Acta 995: 285-290, 1989.

21. Laemmli UK: Cleavage of structural proteins during the assembly of the head of bacteriophage T4. Nature 227: 680-685, 1970 
22. Bradford M: A rapid and sensitive method for the quantitation of microgram quantities of protein utilizing the principle of protein-dye binding. Anal Biochem 72: 248-254, 1976.

23. Rust L, Messing CR and Iglewski BH: Elastase assays. Methods Enzymol 235: 554-562, 1994.

24. Bik EM, Eckburg PB, Gill SR, Nelson KE, Purdom EA, Francois F, Perez-Perez G, Blaser MJ and Relman DA: Molecular analysis of the bacterial microbiota in the human stomach. Proc Natl Acad Sci USA 103: 732-737, 2006.

25. Gao Z, Tseng CH, Pei Z and Blaser MJ: Molecular analysis of human forearm superficial skin bacterial biota. Proc Natl Acad Sci USA 104: 2927-2932, 2007.

26. Roth RR and James WD: Microbiology of the skin: resident flora, ecology, infection. J Am Acad Dermatol 20: 367-390, 1989.

27. O'Hara AM and Shanahan F: The gut flora as a forgotten organ. EMBO Rep 7: 688-693, 2006.

28. Kawai E, Idei A, Kumura H, Shimazaki K, Akatsuka H and Omori $\mathrm{K}$ : The $\mathrm{ABC}$-exporter genes involved in the lipase secretion are clustered with the genes for lipase, alkaline protease, and serine protease homologues in Pseudomonas fluorescens no. 33. Biochim Biophys Acta 1446: 377-382, 1999.

29. Fairbairn DJ and Law BA: Proteinases of psychrotrophic bacteria: their production, properties, effects and control. J Dairy Res 53: 139-177, 1986.
30. Kohlmann KL, Nielsen SS and Ladisch MR: Purification and characterization of an extracellular protease produced by Pseudomonas fluorescens M3/6. J Dairy Sci 74: 4125-4136, 1991.

31. Morita RY: Psychrophilic bacteria. Bacteriol Rev J39: 144-167, 1975.

32. Kumeta H, Hoshino T, Goda T, Okayama T, Shimada T, Ohgiya S, Matsuyama $\mathrm{H}$ and Ishizaki $\mathrm{K}$ : Identification of a member of the serralysin family isolated from a psychrotrophic bacterium, Pseudomonas fluorescens 114. Biosci Biotechnol Biochem 63: 1165-1170, 1999.

33. Uitto J: Biochemistry of the elastic fibers in normal connective tissues and its alterations in diseases. J Invest Dermatol 72: 1-10, 1979.

34. Csiszar K: Lysyl oxidases: a novel multifunctional amine oxidase family. Prog Nucleic Acid Res Mol Biol 70: 1-32, 2001.

35. Smith-Mungo LI and Kagan HM: Lysyl oxidase: properties, regulation and multiple functions in biology. Matrix Biol 16: 387-398, 1998.

36. Rao SK, Mathrubutham M, Karteron A, Sorensen K and Cohen JR: A versatile microassay for elastase using succinylated elastin. Anal Biochem 250: 222-227, 1997. 